Title Page

\title{
Going beyond "regular and casual": development of a classification of sexual partner types to enhance partner notification for sexually transmitted infections, a mixed methods approach
}

Authors: Claudia Estcourt, Paul Flowers, Jackie Cassell, Maria Pothoulaki, Gabriele Vojt, Fiona Mapp, Melvina Woode Owusu, Nicola Low, John Saunders, Merle Symonds, Alison Howarth, Sonali Wayal, Rak Nandwani, Susie Brice, Alex Comer, Anne M Johnson, Catherine Mercer

Corresponding Author: Professor Claudia Estcourt, School of Health and Life Sciences, Glasgow Caledonian University, Glasgow, G4 OBA, UK. claudia.estcourt@gcu.ac.uk

Word count: 2939

Key words: transmission dynamics, sexual health, partner notification, contact tracing, chlamydia infection, gonorrhoea, HIV, STIs, sexual partners

\section{Key messages:}

1. Current classifications of sexual partners limit understanding of STI transmission dynamics and hinder targeting and tailoring of partner notification interventions.

2. The limits and constraints of current classifications, together with recent socio-sexual changes, mean that a new classification is needed.

3. We developed a comprehensive, evidence-based classification of sexual partner types for use in partner notification that characterised and distinguished between partner and partnership types.

4. The five partner categories were readily adopted and easily operationalised in UK sexual health services.

Figures/Tables: 3

Supplementary Table: 1

Figures \& Tables

Figure 1: Initial matrix of sexual partner types and the key features which differentiate them Figure 2: Sexual partner types for clinical practice

Table 1: Use of Theoretical Domains Framework: Implications of the classification of sexual partner types for partner notification approaches

Supplementary Table 1: Table S1: Towards a practical classification of partner types: Interim stage 
medRxiv preprint doi: https://doi.org/10.1101/2020.09.27.20202705; this version posted September 28, 2020. The copyright holder for this

preprint (which was not certified by peer review) is the author/funder, who has granted medRxiv a license to display the preprint in perpetuity.

It is made available under a CC-BY 4.0 International license .

\begin{abstract}
Objectives: To develop a classification of sexual partner types for use in partner notification (PN) and other interventions to prevent sexually transmitted infections (STI).
\end{abstract}

Methods: A four-step process: 1) an iterative synthesis of five sources of evidence: scoping review of social and health sciences literature on partner types; analysis of relationship types in dating apps; systematic review of PN intervention content; review of PN guidelines; qualitative interviews with public, patients and health professionals, to generate an initial comprehensive classification; 2) multidisciplinary clinical expert consultation to revise the classification; 3) piloting of the revised classification in sexual health clinics during a randomised controlled trial of $\mathrm{PN}$; 4) application of the Theoretical Domains Framework (TDF) to identify index patients' willingness to engage in PN for each partner type.

Results: Five main partner types emerged from the evidence synthesis and consultation: 'Established partner', 'New partner', 'Occasional partner', 'One-off partner' and 'Sex worker'. The types differed across several dimensions, including likely perceptions of sexual exclusivity, likelihood of sex reoccurring between index patient and sex partner. Sexual health professionals found the classification easy to operationalise. During the trial, they assigned all 3288 partners described by 2223 index patients to a category. The TDF analysis suggested that the partner types might be associated with different risks of STI reinfection, onward transmission and index patients' engagement with PN.

Discussion: We developed an evidence-informed, useable classification of five sexual partner types to underpin PN practice and other STI prevention interventions. Analysis of biomedical, psychological and social factors that distinguish different partner types shows how each could warrant a tailored PN approach. This classification could facilitate the use of partner-centred outcomes. Additional studies are needed to determine the utility of the classification to improve measurement of the impact of PN strategies and help focus resources. 


\section{Introduction}

Understanding the nature and number of sexual partners of people with sexually transmitted infections (STIS) is fundamental to understanding the epidemiology of STIS, delivery of high quality clinical care, and prevention of transmission through effective partner notification (PN). ${ }^{1-6}$ However, we need appropriate tools to assess to whom and how interventions should be targeted.

Specialist sexual and public health guidance and published researchers tend to use a simple dichotomy of "regular" ("steady") or "casual" sexual partners. ${ }^{3,7-10}$ These categories do not take into account the complexities of sexual partnerships in ways that help understand the potential for STI transmission, or support clinical, research or prevention practice. The outcomes of PN generally specify an overall number of partners contacted/treated per index patient, ${ }^{3}$ ignoring variation in the timing and types of partnerships, the likelihood of onward transmission by partnership type, ${ }^{1}$ or the different kinds of support needed to notify partners effectively. ${ }^{6}$

The way people meet sex partners is changing. Through increasing internet use, ${ }^{11}$ online commercial socio/sexual networking sites have generated their own partner classifications, shaping the ways people understand and talk about relationships. ${ }^{12}$ Public awareness of different types of sexual partners is also increasing, with recognition of sexual interactions where the label of 'partner' is not applicable. These changes are taking place at a time of sustained rises in STIs in some groups. ${ }^{13}$

Social epidemiologists and behavioural scientists have sought to develop alternative ways of classifying partnership type to try and better understand STI and HIV risk (e.g. ${ }^{14-16}$ ), but there is no consensus. As a result, we lack comparable quantitative data for epidemiological studies and service evaluations. A standardised partner type classification, with face validity for both patients and service providers would improve measurement of the impact of PN strategies and help focus resources. ${ }^{17}$ If applied to the practice of PN, a new classification would help a move towards partner-centred outcomes (e.g. transmissions prevented according to partnership type) rather than patient-centred outcomes (e.g. partners tested/treated per index case).

The objectives of this study were to create a useable classification of sexual partners to improve the targeting of PN and other STI prevention interventions. The study addressed four questions: 1) Which labels are used to classify sexual partners and which biomedical, psychological and social aspects differentiate them? 2) What does a classification of sexual partners look like for clinical practice? 3) Is 
this classification acceptable and feasible for routine use? 4) How could use of the classification help to improve individual and public health?

\section{Methods}

This study is part of the Limiting Undetected Sexually Transmitted infections to RedUce Morbidity (LUSTRUM; lustrum.org.uk) research programme. We used mixed research methods within a broad, biopsychosocial approach, acknowledging the importance of psychological, social and cultural factors to the understanding of sexual partnerships. ${ }^{18}$ We used a four-step process: 1) integrating evidence from diverse sources to develop an initial classification, 2) multidisciplinary clinical expert input to revise the classification, 3) piloting the classification in sexual health clinics, 4) application of the Theoretical Domains Framework (TDF) ${ }^{19}$ to explore the need for tailored PN.

(1) Evidence integration: We iteratively synthesised the findings from four diverse sources of evidence:

i) a scoping review of partnership types described in the social and health sciences literature ${ }^{20}$ ii) a review of PN guidelines, ${ }^{21}$ iii) focus group discussions with lay people, including those recently diagnosed with an STI, ${ }^{22}$ and iv) a review of partnership types described in dating apps. ${ }^{12}$

The methods used for each source have been published separately. ${ }^{12,20-22}$

We created a matrix of partner types, according to the key biomedical, psychological and social factors that differentiated them. First, we derived descriptions of partner types from the review of social and health sciences literature. ${ }^{20}$ Second, we used constant comparative techniques, i.e., taking published data and comparing them with our emerging findings and putting 'like with like', to map descriptions of types of relationship and concomitant partner type from the other data sources (the reviews of dating apps, PN intervention content and guidelines, and findings from focus group discussions). We applied the same approach to identify the key biomedical, psychological and social factors that differentiated the particular types of relationships and partners.

(2) Multidisciplinary clinical expert input: Experts provided opinions and suggestions in the following sequence; 1) we discussed initial drafts of the matrix with the full LUSTRUM project team, which includes clinical sexual health and PN specialists, 2) we sought opinions on a revised draft from multidisciplinary clinical sexual health care professionals in a workshop on PN outcomes at a national specialist conference (BASHH Annual Spring Meeting, 2017), 3) a senior team member with clinical 
expertise (CSE) applied the feedback from the workshop participants to examine the conceptual coherence and logic of the matrix. She assessed its utility against a range of real and hypothetical patient scenarios and discussed areas of uncertainty and disagreement with the LUSTRUM team, 4) we simplified the matrix again to improve clinical utility. This process produced the sex partner classification that the project team considered clinically useful, 5) STI clinical, public health and epidemiology experts from UK, Australia and The Netherlands gave further input as part of a BASHH working group to develop PN outcomes in May 2019, and changes were incorporated.

(3) Piloting the classification: We developed a standardised 15-minute training session for healthcare professionals about the refined classification and how to use it during sexual history-taking and PN consultations. The training was part of a randomised controlled trial (RCT) of accelerated partner therapy (APT) for PN for heterosexual people with chlamydia. ${ }^{23}$ Around 120 healthcare professionals (nurses, health advisers and doctors) received the training between 31/05/2018 and 26/09/2018 at 17 sexual health clinics in England and Scotland, which were purposively selected for their contrasting patient populations and geographical contexts. At the end of the training, we administered an informal quiz using patient scenarios. Healthcare professionals practised using the classification and discussed answers collectively. Healthcare professionals used the classification during the pre-trial baseline data collection phase and the first trial period (04/11/2018 to 28/04/2019). As part of the trial's monthly clinic support sessions, we asked each clinic's "trial champion" about their team's experiences using the classification for sexual histories and PN, specifically noting any instances where clinicians had felt unable to assign a particular patient's partner to any category.

(4) Applying the Theoretical Domains Framework (TDF) to the classification: To understand how the classification might enhance PN, we explored how, from an index patient's perspective, relative barriers and facilitators to engaging with PN differed according to partnership type. We used the TDF to code these findings. ${ }^{19}$ In this way, we outlined the differential barriers and facilitators shaping index patient engagement with PN in order to speculate about how the classification might suggest particular tailored PN approaches for different partner types.

\section{Results}

The results are presented in relation to the research questions.

\section{Which labels are used to classify sexual partners and which biomedical, psychological and social aspects differentiate them?}


The evidence integration initially resulted in eight categories, which summarised the range of identified sexual partner types (Figure 1, top row). These types span (from left to right) the traditional dichotomy from "regular" to "casual". The partner types also incorporate trajectories across time, with intensity and duration decreasing from left to right. We identified eight important variables: two in the biomedical domain, four psychological factors and two social aspects, which could help distinguish between partnership types.

From a biomedical perspective, the classification captures the concept that both the likelihood of STI reinfection within the partnership and onwards transmission to other people differ by partner type. ${ }^{1}$ Reinfection with in a partnership is more pertinent for partner types such as 'married/committed' and 'main partner'/'serious partner'/'stable partner'/'long term partner', whilst onward transmission is more of a risk at the opposite end of the partner spectrum ('super casual'/'hook up'/'meet' and 'onenight stand').

We identified four psychological factors that appeared to differ between partner types; higher perceptions of an exclusive partnership, higher likelihood of sex again and more enduring emotional connection are associated with those types at the left-hand side (i.e., towards 'married'/'committed'). In contrast, types characterised by lower expectations of exclusivity, lower likelihood of sexual intercourse with that partner again, little emotional connection and shorter duration cluster on the right-hand side towards the 'super casual'/'hook-up'/'meet'/'one-night stand' partner types.

Social factors also distinguish between partner types. For example, partner types towards the righthand side of Figure 1 are more likely to be embedded within larger, disassortative, multifaceted sexual networks than those towards the left-hand side. Contactability is less clearly polarised and may be possible all across the partner spectrum but is likely to reduce from left to right. 
medRxiv preprint doi: https://doi.org/10.1101/2020.09.27.20202705; this version posted September 28, 2020. The copyright holder for this preprint (which was not certified by peer review) is the author/funder, who has granted medRxiv a license to display the preprint in perpetuity.

It is made available under a CC-BY 4.0 International license .

Figure 1: Initial matrix of sexual partner types and their relation to key factors that differentiate them

\begin{tabular}{|c|c|c|c|c|c|c|c|c|}
\hline $\begin{array}{l}\text { Results of the } \\
\text { Synthesis }\end{array}$ & $\begin{array}{l}\text { Married/I } \\
\text { Committed }\end{array}$ & $\begin{array}{l}\text { Main partner } \\
\text { Serious/ } \\
\text { Stable/Long } \\
\text { term partner }\end{array}$ & Steady & $\begin{array}{l}\text { Girlfriend/ } \\
\text { Boyfriend }\end{array}$ & $\begin{array}{l}\text { Dating/Going } \\
\text { out }\end{array}$ & $\begin{array}{l}\text { Friends with } \\
\text { benefits }\end{array}$ & $\begin{array}{l}\text { Fuck buddies/ } \\
\text { Booty calls }\end{array}$ & $\begin{array}{l}\text { Super casual/ } \\
\text { Hook-up// } \\
\text { Meet } \\
\text { One night } \\
\text { stand }\end{array}$ \\
\hline \multicolumn{9}{|c|}{ Biological/biomedical aspects of sexual partner types in relation to STI and PN } \\
\hline Reinfection & \multicolumn{3}{|c|}{ High risk of reinfection } & \multicolumn{3}{|c|}{ 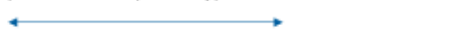 } & \multicolumn{2}{|c|}{ Low risk of reinfection } \\
\hline $\begin{array}{l}\text { Onwards } \\
\text { Transmission }\end{array}$ & Low risk & & & & & & \multicolumn{2}{|c|}{ High risk } \\
\hline
\end{tabular}

Psychological aspects of sexual partner types in relation to STIs and PN

\begin{tabular}{l|l|l} 
Sexual exclusivity & High perceptions of exclusivity \\
\hline $\begin{array}{l}\text { Likelihood of sex } \\
\text { again }\end{array}$ & High likelihood of sex again \\
\hdashline $\begin{array}{l}\text { Affective } \\
\text { dimensions }\end{array}$ & Enduring emotional connection \\
\hline $\begin{array}{l}\text { Duration of the } \\
\text { partnership }\end{array}$ & Long term \\
\hline Sontact-ability & Highly contactable & Low perceptions of exclusivity \\
\hline $\begin{array}{l}\text { Type of sexual } \\
\text { network }\end{array}$ & Smaller and more assortative & Sotentially contactable
\end{tabular}

Legend to Figure 1: Evidence synthesis derived an initial eight partner types (top row). Factors which differentiated them are shown in the left hand column.

\section{What does a classification of sexual partners look like for clinical practice?}

We simplified the initial classification from eight to four categories to make it practical for use in clinical care, based on the multidisciplinary clinical expert input (Figure 2). The clinician researchers recommended adding a fifth category of sex partner "Sex worker", which had not emerged from the scoping review as a separate partnership type. A separate category for sex work reflects UK national guidance on sexual history-taking ${ }^{24}$ and because PN and risk reduction strategies are likely to differ for this group. The research team assigned short neutral labels to each category as an aide-memoire for health care professionals. The labels are not intended to be used as descriptors in consultations with patients although some of the words used may figure in patients' descriptions of their relationships, e.g. "One-offs", "Sex worker".

\section{Is the classification acceptable and feasible for use in routine clinical practice?}

Informal verbal feedback from the pre-trial teaching sessions was overwhelmingly positive.

Participants agreed that the new categories could help overcome the well-recognised limitations of the "regular/casual" dichotomy. Participants correctly assigned partners to categories in the posttraining skills test. During the trial baseline data collection phase, we discussed and resolved categories for a small number of clinical cases, raised by clinical staff. There were no further queries after starting 
medRxiv preprint doi: https://doi.org/10.1101/2020.09.27.20202705; this version posted September 28, 2020. The copyright holder for this preprint (which was not certified by peer review) is the author/funder, who has granted medRxiv a license to display the preprint in perpetuity.

It is made available under a CC-BY 4.0 International license .

the trial and by the end of the first trial period (04/11/2018 to 28/04/2019), clinicians across the 17

study sites had used the classification to categorise 3288 sex partners from 2223 index patients. There

were no instances in which clinicians felt unable to assign a sex partner to any category. Figure 2

summarises the partner types for use by healthcare professionals in sexual health clinics. 
medRxiv preprint doi: https://doi.org/10.1101/2020.09.27.20202705; this version posted September 28, 2020. The copyright holder for this preprint (which was not certified by peer review) is the author/funder, who has granted medRxiv a license to display the preprint in perpetuity.

It is made available under a CC-BY 4.0 International license .

Figure 2: Partner Types for clinical practice

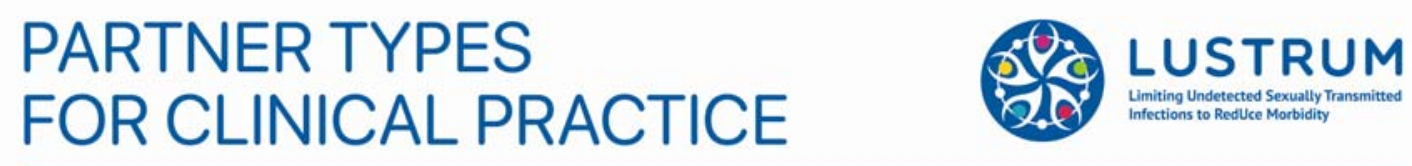

When to use: This grid may be used in any setting to support discussions about sexual partners and relationships. It may be particularly useful for STI partner notification and contact tracing and to discuss people's sexual networks. However, in cases of sexual assault, alternatives may be more appropriate. How to use: This grid may be used in any setting to support discussions about sexual partners and relationships. It may be particularly useful for STI partner notification and contact tracing and to discuss people's sexual networks. However, in cases of sexual assault, alternatives may be more appropriate.

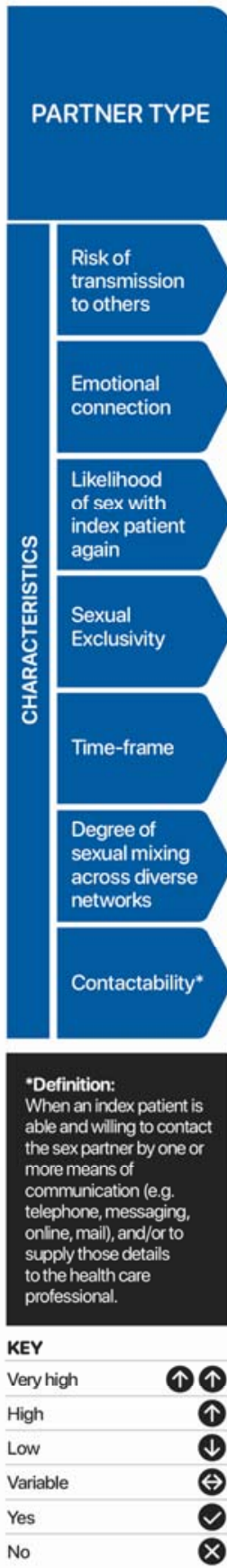

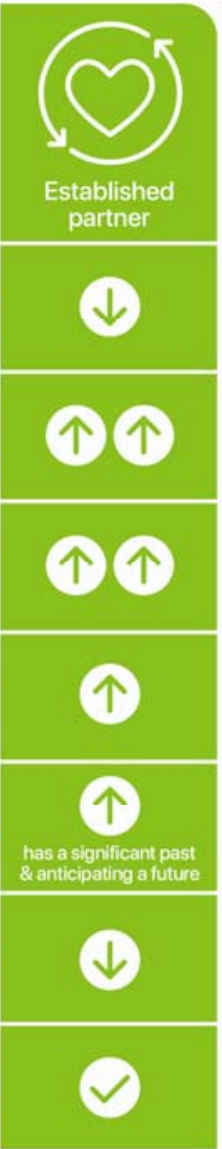

Established partner: This could be a primary partner (e.g. spouse/civil partner, wife/husband) or a long-term 'affair'). a long-term 'affair').
There is often a high likelihood of this being a stable relationship, characterised by some all of the following features: a significant past, regular sex future-oriented, highly developed romantic emotional connection, co-habiting.

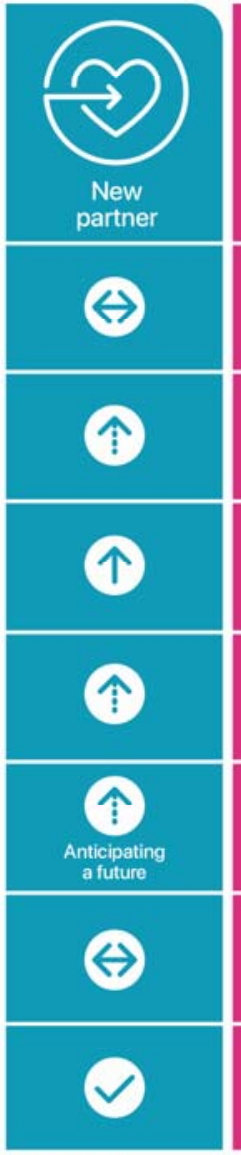

New partner: This could be person with whom the index patient is likely to have had sex on more than one occasion. Their relationship may be characterised by som features: little/nopast growing romantic emotional connection and intentions to form astable relationship in the future.

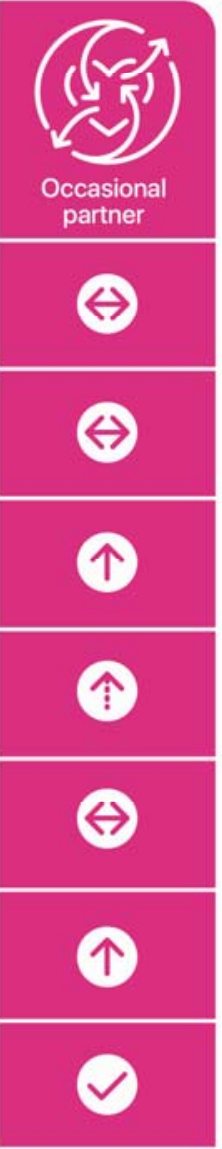

Occasional partner: This could be a person with whom the index patient has had sex on more than one occasion and with whom there is an expectation of sex again, on a sporadic or regular basis. Their relationship may be characterised by some or all of the following features: no or low anticipation of a stable partnership forming, no or minimal romantic emotional connection, sex for pleasure. It is likely that the partner/index patient is also engaging in concurrent sex with other partners/other partner types.

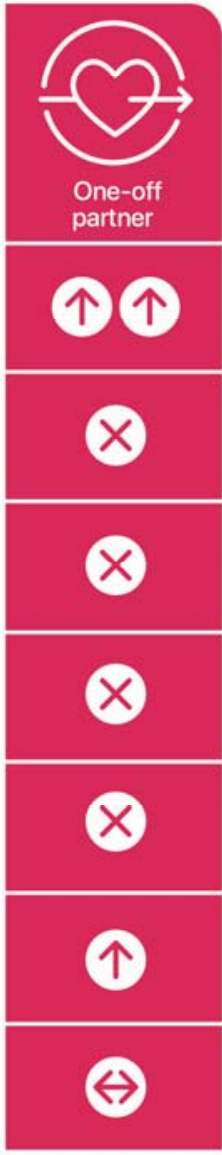

One-off partner: This could be a person with whom the index patient has had sex on one occasion only, most likely for pleasure or recreation. Characteristics which might help identify this type of partner include: no past and no future, no anticipation of sex again, little/no romantic emotional connection.

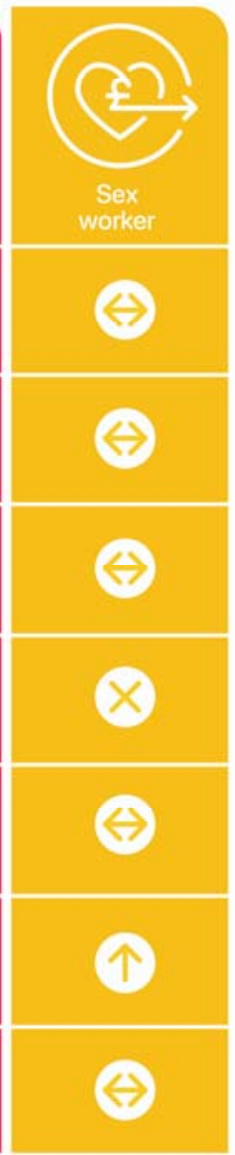

Sexworker:

This could be a person to whom the index patient has provided money or goods in direct exchange or sexual services. The term sex worker encompasses a wide range of types of sex work with variable risks of STI\& HIV transmission. Partners identified as sex workers by index patients may share characteristic with those suggested for one or more alternative partner types.

National Institute for Health Research This study is finded by the National institute for Heath Research (N) HR?

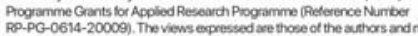

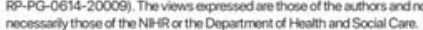


medRxiv preprint doi: https://doi.org/10.1101/2020.09.27.20202705; this version posted September 28, 2020. The copyright holder for this preprint (which was not certified by peer review) is the author/funder, who has granted medRxiv a license to display the preprint in perpetuity.

It is made available under a CC-BY 4.0 International license .

\section{How could use of the classification help to improve individual and public health for PN?}

Table 1 illustrates the ways that the different partner types within the classification may need different

PN approaches.

Table 1: Use of Theoretical Domains Framework: Implications of the classification of partner types for partner notification approaches

\begin{tabular}{|c|c|c|c|c|}
\hline $\begin{array}{l}\text { Partner } \\
\text { Type* }\end{array}$ & Established partner & New partner & Occasional partner & One-off partner \\
\hline \multirow{4}{*}{$\begin{array}{l}\text { Selected } \\
\text { Theoretical } \\
\text { Domains } \\
\text { Framework } \\
\text { functions } \\
\text { that } \\
\text { discriminate } \\
\text { index } \\
\text { patient's } \\
\text { engagement } \\
\text { in PN }\end{array}$} & \multicolumn{4}{|c|}{ Knowledge } \\
\hline & $\begin{array}{l}\text { - Good knowledge of the } \\
\text { partner likely which } \\
\text { might facilitate PN; the } \\
\text { index patient may } \\
\text { anticipate their reaction } \\
\text { and their respective } \\
\text { choice of PN approach }\end{array}$ & $\begin{array}{l}\text { - Uncertain knowledge of } \\
\text { the partner, their } \\
\text { reactions, their choice of } \\
\text { PN approach }\end{array}$ & $\begin{array}{l}\text { - Good knowledge of the } \\
\text { partner likely which } \\
\text { might facilitate PN; the } \\
\text { index patient may } \\
\text { anticipate their reaction } \\
\text { and their respective } \\
\text { choice of PN approach }\end{array}$ & $\begin{array}{l}\text { Very little of the partner may } \\
\text { facilitate or constrain, engagement } \\
\text { in PN }\end{array}$ \\
\hline & \multicolumn{4}{|c|}{ Social role and identity } \\
\hline & $\begin{array}{l}\text { - (e.g., spousal roles) may } \\
\text { facilitate motivation to } \\
\text { engage in PN according } \\
\text { to scripts, expectations } \\
\text { and assumptions }\end{array}$ & $\begin{array}{l}\text { - (e.g., romantic roles) } \\
\text { may constrain } \\
\text { engagement in } \mathrm{PN} \text {, } \\
\text { although novelty of } \\
\text { relationship 'permits' } \\
\text { residual infections } \\
\text { - }\end{array}$ & $\begin{array}{l}\text { - scripts and norms (e.g., } \\
\text { 'friends with benefits') } \\
\text { may enable engagement } \\
\text { in PN } \\
\text { - }\end{array}$ & $\begin{array}{l}\text { - identities (e.g., being a player) } \\
\text { may constrain engagement in PN }\end{array}$ \\
\hline \multirow[t]{3}{*}{$\begin{array}{l}\text { Implications } \\
\text { for PN }\end{array}$} & $\begin{array}{l}\text { Beliefs about the } \\
\text { consequences of } \\
\text { engaging in PN are } \\
\text { important and varied } \\
\text { (health, interpersonal, } \\
\text { infidelity) }\end{array}$ & $\begin{array}{l}\text { Beliefs about the } \\
\text { consequences of } \\
\text { engaging in PN are } \\
\text { important and varied } \\
\text { (health, interpersonal, } \\
\text { end of the relationship) }\end{array}$ & $\begin{array}{l}\text { - Beliefs about the } \\
\text { consequences of } \\
\text { engaging in PN are } \\
\text { probably health } \\
\text { oriented and may } \\
\text { facilitate PN }\end{array}$ & $\begin{array}{l}\text { - Likely to have minimal concerns } \\
\text { about the consequences of } \\
\text { engaging in PN }\end{array}$ \\
\hline & $\begin{array}{l}\text { Emotions may be } \\
\text { particularly important } \\
\text { given length of } \\
\text { relationship and likely } \\
\text { expectations of } \\
\text { exclusivity }\end{array}$ & $\begin{array}{l}\text { Emotions may be } \\
\text { particularly important } \\
\text { given potential } \\
\text { emerging expectations } \\
\text { of exclusivity, they may } \\
\text { be particularly intense }\end{array}$ & $\begin{array}{l}\text { Emotions may be less } \\
\text { important and not } \\
\text { represent barriers to } \\
\text { engaging in PN }\end{array}$ & $\begin{array}{l}\text { - Emotions are not likely to be } \\
\text { important in relation to engaging } \\
\text { in PN }\end{array}$ \\
\hline & $\begin{array}{l}\text { - Highly amenable to PN } \\
\text { interventions that utilise } \\
\text { the existing relationship } \\
\text { dynamics, rapid } \\
\text { effective access to } \\
\text { partners, established } \\
\text { routes of } \\
\text { communication and } \\
\text { almost guaranteed } \\
\text { future interactions } \\
\text { between partners }\end{array}$ & $\begin{array}{l}\text { - PN interventions that } \\
\text { rely on existing } \\
\text { relationship dynamics } \\
\text { may be problematic, } \\
\text { access to partners may } \\
\text { be difficult }\end{array}$ & $\begin{array}{l}\text { - Highly amenable to PN } \\
\text { interventions that can } \\
\text { utilise the existing } \\
\text { relationship dynamics, } \\
\text { established means of } \\
\text { access to partners, } \\
\text { established routes of } \\
\text { communication and } \\
\text { almost guaranteed } \\
\text { future interactions } \\
\text { between partners }\end{array}$ & $\begin{array}{l}\text { - PN for these types of partner } \\
\text { maybe more resource intensive } \\
\text { as index patients may have low } \\
\text { motivation to engage in PN. }\end{array}$ \\
\hline
\end{tabular}




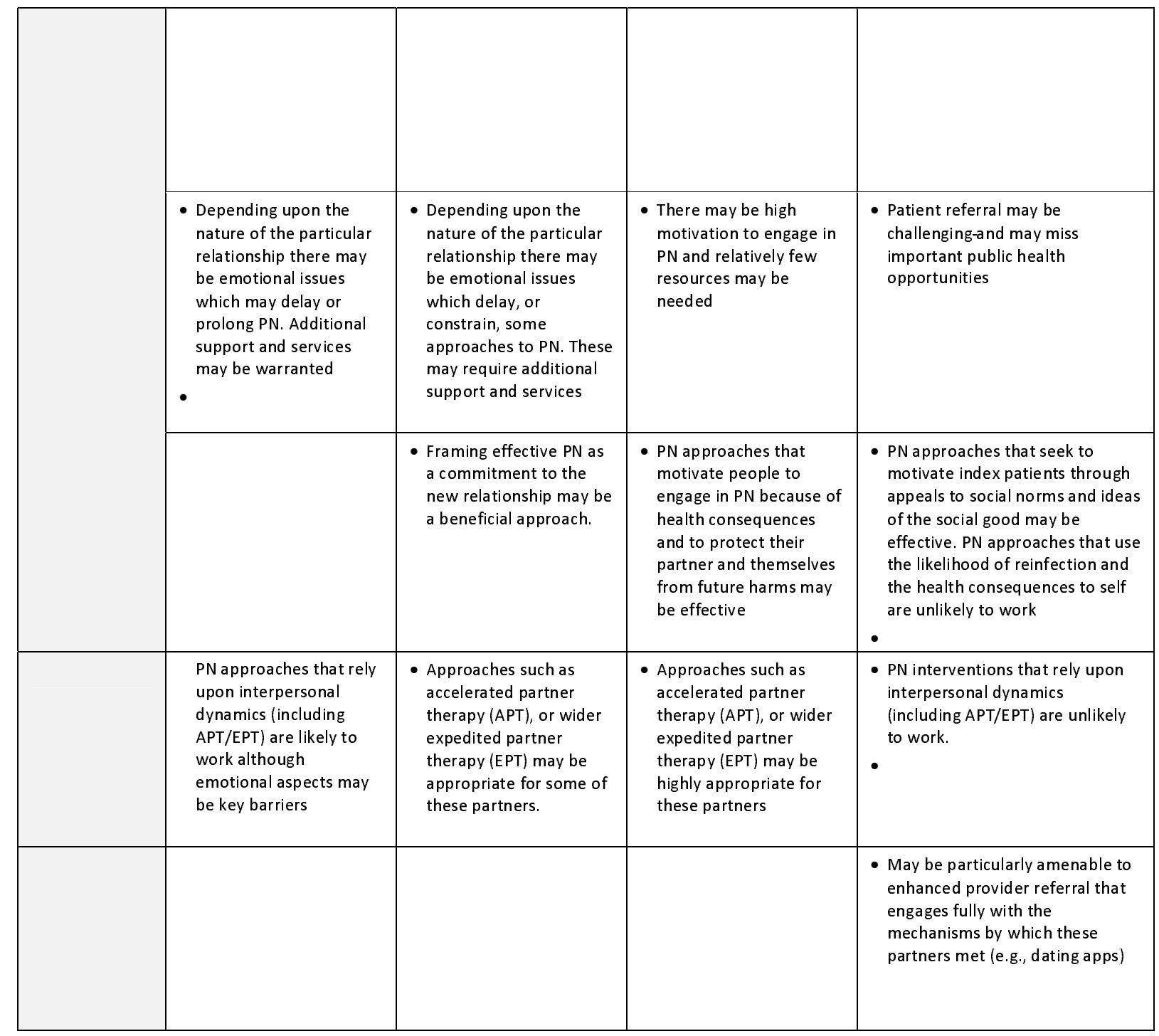

*The sex worker partner type was added to the classification after completion of this phase of work and so was not included in the TDF analysis.

For any index patient with multiple sexual partners, the $\operatorname{TDF}^{19}$ suggests it may be worth exploring which type(s) of sexual partner(s) they have, and subsequently which type(s) of PN may be most appropriate for each different partner, depending on their type. Critically, although an index patient may have equal physical capability to engage in $\mathrm{PN}$ with diverse types of partner, there are important differences in the index patient's motivation to engage in $\mathrm{PN}$ with different partner types. For example, from an index patient's perspective, there may be very little motivation to engage in PN with 'One-off partners' and far more to engage with 'Established partners' with whom sex is likely to occur again.

For 'Established partners', PN approaches should utilise the deep emotional connection between partners, the likelihood of co-habitation and the high potential for reinfection. Approaches such as 
Expedited Partner Therapy, ${ }^{25}$ and Accelerated Partner Therapy ${ }^{23}$ are likely to be acceptable and effective. Depending on the particular relationships and expectations concerning exclusivity, PN may be taking place against a background of high emotions and potential distress; partner delivered testing/treatment options may be very useful.

For 'New partners', PN approaches should harness the developing emotions within such relationships and capitalise upon the relationship's short duration. For these relationships a diagnosis of an STI can 'make or break' the developing relationship. For example, it may be that the STI has arisen from sex pre-dating the current 'new' relationship, or that the STI has been transmitted before agreements concerning exclusivity have been made.

For 'Occasional partners' characterised by high likelihood of the relationship having a future and likely sex again, yet limited emotions, approaches such as Expedited Partner Therapy, ${ }^{25}$ and Accelerated Partner Therapy ${ }^{23}$ may be highly acceptable.

For 'One-off partners', PN approaches which require an emotional connection between partners, or those that use risks of reinfection to motivate partners or are unlikely to be effective. However, given changes in the ways people meet and the widespread use of social media, index patients may well have some means of contacting these types of sexual partner. Provider referral, in which the health care professional contacts the sex partner without revealing the identity of the index patient may be useful.

\section{Discussion}

We developed a new five-category classification of sex partner types. We synthesised diverse sources of evidence to understand the biomedical, psychological and social aspects that make the partner types identified distinct. The classification was feasible and acceptable to a range of healthcare professionals within sexual health services across England and Scotland. The classification accommodates most sex partner types described by people attending UK sexual health services and staff were able to assign all sex partners described to a category.

For use in routine clinical care, a classification needs to be pragmatic, such that the majority of partner types described in contemporary life and clinical practice can be assigned to a reasonable number of categories, whilst recognising that some patients will describe partners who cannot be neatly assigned to any category. Our proposed classification goes beyond the mutually exclusive dichotomy of 'regular' 
or 'casual' partnerships that has been used in sexual health practice to date. By synthesising diverse sources of evidence, our classification considers the realities and increasing complexities of the contemporary social organisation of sexual relationships.

This work has drawn on, and further developed, existing classifications that typically focus on a single dataset and/or consider fewer partnership-specific variables to differentiate between the types identified. The classification has important differences from an earlier classification that was based on responses to questions in the third British National Survey of Sexual Attitudes and Lifestyles (Natsal3). ${ }^{16}$ Questions in Natsal-3 distinguished between partnerships that involved cohabiting and those that were considered as 'now steady'. We now propose using the collective label of 'Established'. Whilst the earlier classification had just one category for 'casual' partners, we now propose two categories: 'Occasional' partners and 'One-off' partners. This distinction is helpful because of the greater heterogeneity in casual sex (and the labels attributed to this) as compared with more established partnerships. The distinction is also relevant to the delivery of PN, reflecting variation in the extent that different types of casual partners can be traced and/or contacted.

The partner types that emerged are culturally embedded in UK sexual health settings. Although we searched the international literature, the classification might not be generalisable to very different populations or cultures. Whilst we piloted the usability of the classification during a trial that included only people who have sex with opposite gender partners, the partner types also make sense for same sex partnerships and those that include trans/transgender and non-binary people. The classification takes account of current societal sexual behaviours and so may not be relevant if significant shifts in sexual behaviours occur.

A pragmatic, evidence-informed classification could enhance clinical practice and research study design. More appropriate targeting and tailoring of PN and other sexual health interventions should result in greater individual and public health benefits. Whilst our classification prioritises utility within the clinical context rather than the general population, it is informed by published evidence and primary research undertaken with people in a variety of settings, including clinic attendees and lay people.

The classification could improve the ability of services to address the aims of PN at both individual patient level (prevention of reinfection) and public health level (transmission prevention) by ensuring that the best available evidence guides the choice of PN methods offered by services. Tailored PN 
medRxiv preprint doi: https://doi.org/10.1101/2020.09.27.20202705; this version posted September 28, 2020. The copyright holder for this

preprint (which was not certified by peer review) is the author/funder, who has granted medRxiv a license to display the preprint in perpetuity.

It is made available under a CC-BY 4.0 International license .

approaches should enable more effective targeting of resources and audit that is meaningful in epidemiological terms, as well as relating to the individual index patient. This methodological advance will also enhance social epidemiology and the evidence provided by behavioural surveillance to facilitate development of patient-centred risk assessment tools. Such tools will enable robust comparisons of the transmission prevention outcomes of existing and novel PN approaches as well as index patient-centred outcomes. Collectively, these advances could improve patient care by ensuring that best-available evidence guides choice of PN methods offered by services. At the individual patient level, an awareness of the distinct aspects of each partner type could enable better tailoring of PN interventions offered by health care professionals and allow a more strategic approach to prevention of transmission. This offers considerable potential when PN is particularly important at both the individual and public health level, such as with cases of extensively drug-resistant pathogens. ${ }^{26}$

The content validity of the classification is being evaluated in the RCT of accelerated partner therapy, ${ }^{23}$ which will include analysis of trial outcomes by partner type. Evaluation in clinical practice through a UK national audit will take place in 2020 and will establish whether the classification accommodates most sex partner descriptions, including same sex partners, when embedded in routine care.

Additional studies are needed to determine the utility of the classification to improve measurement of the impact of PN strategies and help focus resources. Future work will address tailored intervention development based on partner type, which could inform targeting of resources to reach sex partners who might contribute disproportionately to transmission within the population. New PN methods will need to embrace the range of communication technologies used within contemporary social and sexual networks and determine the cost-effectiveness of PN approaches with different types of partner in relation to reducing onwards transmission at the population level. 
medRxiv preprint doi: https://doi.org/10.1101/2020.09.27.20202705; this version posted September 28, 2020. The copyright holder for this preprint (which was not certified by peer review) is the author/funder, who has granted medRxiv a license to display the preprint in perpetuity.

It is made available under a CC-BY 4.0 International license .

\section{Supplementary File:}

\begin{tabular}{|c|c|c|c|c|c|c|c|c|c|}
\hline $\begin{array}{l}\text { Table S1: } \\
\text { Towards a } \\
\text { practical } \\
\text { classification of } \\
\text { partner types: } \\
\text { Interim } \\
\text { stage Partner } \\
\text { label/ name }\end{array}$ & \multicolumn{2}{|c|}{$\begin{array}{l}\text { Established } \\
\text { partner }\end{array}$} & \multicolumn{3}{|c|}{ New Partner } & \multicolumn{2}{|c|}{ Occasional partner } & $\begin{array}{l}\text { One-off } \\
\text { partner }\end{array}$ & Sex worker \\
\hline $\begin{array}{l}\text { Categories of } \\
\text { partner from the } \\
\text { initial matrix } \\
\text { (Figure 1) }\end{array}$ & $\begin{array}{l}\text { Married } \\
\text { Committed }\end{array}$ & $\begin{array}{l}\text { Main } \\
\text { Partner } \\
\text { Serious } \\
\text { Partner } \\
\text { Stable } \\
\text { Long } \\
\text { term }\end{array}$ & Steady & $\begin{array}{l}\text { Girlfriend } \\
\text { Boyfriend }\end{array}$ & $\begin{array}{l}\text { Dating } \\
\text { Going } \\
\text { Out }\end{array}$ & $\begin{array}{l}\text { Friends } \\
\text { with } \\
\text { benefits }\end{array}$ & $\begin{array}{l}\text { Fuck } \\
\text { buddies } \\
\text { Booty } \\
\text { calls }\end{array}$ & $\begin{array}{l}\text { Super casual } \\
\text { Hook up } \\
\text { Meet } \\
\begin{array}{l}\text { One-night } \\
\text { stand }\end{array}\end{array}$ & \\
\hline $\begin{array}{l}\text { Key factors } \\
\text { differentiating } \\
\text { partner types } \\
\text { (from Figure 1) }\end{array}$ & \multicolumn{2}{|c|}{$\begin{array}{l}\text { - Very high chance of } \\
\text { reinfection } \\
\text { - Low chance of } \\
\text { onward transmission } \\
\text { to others } \\
\text { - High chance of } \\
\text { expectations of sexual } \\
\text { exclusivity } \\
\text { - Very high chance of } \\
\text { sex again } \\
\text { - Enduring deep } \\
\text { emotional connection } \\
\text { - Longer term } \\
\text { relationship } \\
\text { - Highly contactable } \\
\text { - High likelihood of } \\
\text { small assortative } \\
\text { sexual mixing }\end{array}$} & \multicolumn{3}{|c|}{$\begin{array}{l}\text { - High chance of reinfection } \\
\text { - Some chance of on ward } \\
\text { transmission } \\
\text { - High chance of sex again } \\
\text { - Developing emotional } \\
\text { connection } \\
\text { - Developing time frame for } \\
\text { the relationship } \\
\text { - Highly contactable } \\
\text { - High likelihood of small } \\
\text { assortative sexual mixing }\end{array}$} & \multicolumn{2}{|c|}{$\begin{array}{l}\text { - High chance of } \\
\text { reinfection } \\
\text { - Some chance of } \\
\text { onward transmission } \\
\text { - High chance of sex } \\
\text { again } \\
\text { - Stable emotional } \\
\text { connection } \\
\text { - Potentially enduring } \\
\text { relationships } \\
\text { - Highly contactable } \\
\text { - Stable relationship } \\
\text { - Highly contactable }\end{array}$} & $\begin{array}{l}\text { - Low chance } \\
\text { of reinfection } \\
\text { - High chance } \\
\text { of onward } \\
\text { transmission } \\
\text { - Low } \\
\text { perception of } \\
\text { sexual } \\
\text { exclusivity } \\
\text { - Low } \\
\text { likelihood of } \\
\text { sex again } \\
\text { - Little } \\
\text { emotional } \\
\text { connection } \\
\text { - Short or } \\
\text { fleeting } \\
\text { relationships } \\
\text { - Potentially } \\
\text { contactable } \\
\text { - High } \\
\text { likelihood of } \\
\text { large } \\
\text { disassortative } \\
\text { sexual mixing } \\
\text { within a large } \\
\text { sexual } \\
\text { network }\end{array}$ & \\
\hline $\begin{array}{l}\text { Further } \\
\text { explanatory notes }\end{array}$ & \multicolumn{2}{|c|}{$\begin{array}{l}\text { - Could be primary } \\
\text { partner - spouse/civil } \\
\text { partner wife/husband } \\
\text { - Could be secondary } \\
\text { partner-include } \\
\text { someone's long term } \\
\text { 'affair' } \\
\text { - High likelihood of } \\
\text { stable relationship } \\
\text { - Regular sex } \\
\text { - Future orientation - } \\
\text { will have a significant } \\
\text { past } \\
\text { - Potential co-habiting }\end{array}$} & \multicolumn{3}{|c|}{$\begin{array}{l}\text { - Almost always sex on more } \\
\text { than one occasion } \\
\text { - Future orientation - may } \\
\text { or may not have much of a } \\
\text { past } \\
\text { - Growing emotional } \\
\text { connection } \\
\text { - High likelihood of a labile } \\
\text { relationship }\end{array}$} & \multicolumn{2}{|c|}{$\begin{array}{l}\text { - Sex at least on more } \\
\text { than one occasion } \\
\text { - Anticipation of sex } \\
\text { again } \\
\text { - No relationship } \\
\text { potential } \\
\text { - Sex } \\
\text { intermittent/irregular } \\
\text { - Non-romantic } \\
\text { emotional } \\
\text { connection } \\
\text { - Sex for pleasure } \\
\text { - Between other kinds } \\
\text { of partners } \\
\text { - Sporadic } \\
\text { - Sex with eyes } \\
\text { - Concurrent } \\
\text { - Some likelihood of } \\
\text { stable relationships }\end{array}$} & $\begin{array}{l}\text { - One occasion } \\
\text { only } \\
\text { - No } \\
\text { anticipation } \\
\text { of sex again } \\
\text { - No past no } \\
\text { future } \\
\text { - Little/no } \\
\text { emotional } \\
\text { connection } \\
\text { - Recreational } \\
\text { Sex } \\
\text { - High } \\
\text { likelihood of } \\
\text { labile } \\
\text { relationship }\end{array}$ & $\begin{array}{l}\text { - Sex in return } \\
\text { for money or } \\
\text { services/ } \\
\text { goods }\end{array}$ \\
\hline
\end{tabular}


medRxiv preprint doi: https://doi.org/10.1101/2020.09.27.20202705; this version posted September 28, 2020. The copyright holder for this preprint (which was not certified by peer review) is the author/funder, who has granted medRxiv a license to display the preprint in perpetuity.

It is made available under a CC-BY 4.0 International license .

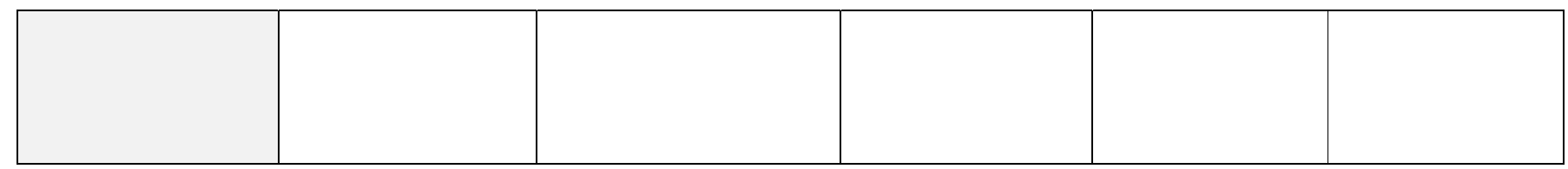

Legend for Table S1: The first row of the table shows the condensed, five-type partner typology, with the second row illustrating how they relate to the 'original' eight partner types described in Figure 1 . The third row summarises the spectrum of issues detailed in Figure 1. 


\section{References}

1. Wasserheit JN, Aral SO. The Dynamic Topology Of Sexually Transmitted Disease Epidemics: Implications For Prevention Strategies. J Infect Dis. 1996;174(Suppl 2):S201-13.

2. Manavi K, Bhaduri S, Tariq A. Audit on the success of partner notification for sexually transmitted infections in the West Midlands. Int J STD AIDS. 2008;19(12):856-8.

3. Brook G, Bacon L, Evans C, McClean H, Roberts C, Tipple C, et al. 2013 UK national guideline for consultations requiring sexual history taking. Clinical Effectiveness Group British Association for Sexual Health and HIV. Int J STD AIDS. 2014;25(6):391-404.

4. Sullivan A. Partner notification for HIV: maximising positive outcomes. In: Third Joint Conference of the British HIV Association (BHIVA) with the British Association for Sexual Health and HIV (BASHH). Liverpool, UK; 2014.

5. McClean H, Carne CA, Sullivan AK, Radcliffe KW, Ahmed-Jushuf I, National Audit Group of British Association for Sexual Health and HIV. Chlamydial partner notification in the British Association for Sexual Health and HIV (BASHH) 2011 UK national audit against the BASHH Medical Foundation for AIDS and Sexual Health Sexually Transmitted Infections Management Standards. Int J STD AIDS. 2012 Oct;23(10):748-52.

6. Ferreira A, Young T, Mathews C, Zunza M, Low N. Strategies for partner notification for sexually transmitted infections, including HIV. Cochrane Database Syst Rev. 2013;(10):Art. No.: CD002843.

7. Nelson LE, Morrison-Beedy D, Kearney MH, Dozier A. Sexual Partner Type Taxonomy Use Among Black Adolescent Mothers in the United States. Can J Hum Sex. 2011;20(1):1-10.

8. European Centre for Disease Prevention and Control. Core indicators - Toolkit Material [Internet]. [Accessed 01.05.2020]. Available from: https://www.ecdc.europa.eu/en/coreindicators

9. Lansky A, JC T, JA E. Partner-specific sexual behaviors among persons with both main and other partners. Fam Plann Perspect. 1998;30(2):93-6.

10. Macaluso M, MJ D, LM A, III HE. Partner type and condom use. AIDS. 2000;14(5):537-46.

11. Cabecinha M, Mercer CH, Gravningen K, Aicken C, Jones KG, Tanton C, et al. Finding sexual partners online: Prevalence and associations with sexual behaviour, STI diagnoses and other sexual health outcomes in the British population. Sex Transm Infect. 2017 Dec 1;93(8):57282.

12. Vojt G, Smith M, Woode Owusu M, Mapp F, Pothoulaki M, Estcourt CS, et al. The Functionality of Dating Applications in Sexual Relationships and Sexual Health. In: British Association of Sexual Health and HIV Annual Conference. Belfast; 2017.

13. Mitchell H, Allen H, Sonubi T, Kuyumdzhieva G, Harb A, Shah A, et al. Sexually transmitted infections and screening for chlamydia in England, 2019. London, England; 2020. Available from: https://assets.publishing.service.gov.uk/government/uploads/system/uploads/attachment_d ata/file/914184/STI_NCSP_report_2019.pdf

14. Buchanan DR, Poppen PJ, Reisen CA. The nature of partner relationship and aids sexual risktaking in gay men. Psychol Heal. 1996;11(4):541-55.

15. Wentland JJ, Reissing E. Casual sexual relationships: Identifying definitions for one night stands, booty calls, fuck buddies, and friends with benefits. Can J Hum Sex. 2014;23(3):16777.

16. Mercer $\mathrm{CH}$, Jones KG, Johnson AM, Lewis R, Mitchell KR, Gravningen K, et al. How can we objectively categorise partnership type? A novel classification of population survey data to inform epidemiological research and clinical practice. Sex Transm Infect. 2017;93(2):129-36.

17. Mercer CH, Aicken CRH, Brook MG, Estcourt CS, Cassell JA. Estimating the likely public health impact of partner notification for a clinical service: An evidence-based algorithm. Am J Public Health. 2011 Nov 1;101(11):2117-23. 
18. Engel GL. The Need for a New Medical Model: A Challenge for Biomedicine. Science (80- ). 1977;196(4286):129-36.

19. Cane J, O'Connor D, Michie S. Validation of the theoretical domains framework for use in behaviour change and implementation research. Implement Sci. 2012 Apr 24

20. Vojt G, Pothoulaki M, Laidlaw R, Flowers P. What do we know about types of intimate relationship and associated sexual partners - A scoping review of interdisciplinary literature. SocArXiv; 2020

21. Wayal S, Estcourt C, Mercer C, Saunders J, Low N, McKinnon T, et al. BASHH Partner Notification Outcome Measures for Bacterial STIs. London, England; 2019.

22. Pothoulaki M, Vojt G, Mapp F, Owusu MW, Mercer C, Estcourt C, et al. The social organisation of sexual relationships: an exploratory qualitative study. SocArXiv; 2020

23. Estcourt CS, Howarth AR, Copas A, Low N, Mapp F, Woode Owusu M, et al. Accelerated partner therapy (APT) partner notification for people with Chlamydia trachomatis: Protocol for the Limiting Undetected Sexually Transmitted infections to RedUce Morbidity (LUSTRUM) APT cross-over cluster randomised controlled trial. BMJ Open. 2020 Mar;10(3):34806.

24. Brook G, Church H, Evans C, Jenkinson N, McClean H, Mohammed H, et al. UK National Guideline for consultations requiring sexual history taking, 2019 Clinical Effectiveness Group British Association for Sexual Health and HIV. 2019.

25. Golden MR, Whittington WLH, Handsfield HH, Hughes JP, Stamm WE, Hogben M, et al. Effect of Expedited Treatment of Sex Partners on Recurrent or Persistent Gonorrhea or Chlamydial Infection. N Engl J Med. 2005;352:676-85.

26. Public Health England. Two cases of resistant gonorrhoea diagnosed in the UK [Accessed 13.08.2020]. 2019. Available from: https://www.gov.uk/government/news/two-cases-ofresistant-gonorrhoea-diagnosed-in-the-uk

Acknowledgements: We would like to thank all of the participants who took part in focus groups and interviews and all individuals and organisations who helped with recruitment for this study via social media, word of mouth and direct contact to their networks. We are also very grateful to the expert group who attended the BASHH PN Outcomes workshop (Ann Sullivan, Ana Harb, Martin Murchie, Ceri Evans, Jonathon O'Sullivan, Hannelore Gotz, Jane Hocking). Thanks to Ceri Evans and Sophie Herbert for their input into Figure 2 and to Lock Cheung Hwa at Diva Creative for the graphic design; thanks to Morgan Williamson for help with figure 1 . This study has been shaped through ongoing discussion and support from the whole LUSTRUM team (Claudia S Estcourt (Principal Investigator), Alex Comer, Alison R Howarth, Andrew Copas, Anna Tostevin, Anne M Johnson, Catherine H Mercer, Chidubem (Duby) Ogwulu, Christian Althaus, Fiona Mapp, Gabriele Vojt, Jackie Cassell, Jean McQueen, John Saunders, Karen Pickering, Maria Pothoulaki, Melvina Woode Owusu, Merle Symonds, Nicola Low, Oliver Stirrup, Paul Flowers, Rak Nandwani, Sonali Wayal, Susannah Brice, Tracy Roberts) and the Programme Steering Committee (PSC) (Simon Barton (chair), Alex Miners, Artemis Koukounari, David Crundwell, Emmanuel Rollings-Kamara, Lynis Lewis, Rebecca Turner, Robbie Currie, Rachel Shaw, Saima Saddiqui (on behalf of NIHR programme management).

Funding statement: This work presents independent research funded by the National Institute for Health Research (NIHR) under its Programme Grants for Applied Research Programme (reference number RP-PG0614-20009). The views expressed are those of the author(s) and not necessarily those of the NIHR or the Department of Health and Social Care. The funders had no role in study design, collection, management, analysis and interpretation of data; writing of the report and the decision to submit the report for publication.

Ethical approval: Ethical approval received from Glasgow Caledonian University Research Ethics Committee (HLS/PSWAHS/A15/256) and NHS Ethics Approval (16/NI/0211) were obtained. Trial: Ethical approval received from London Chelsea Research Ethics Committee (18/LO/0773). 